\title{
International Trade and Investment Sanctions
}

\author{
POTENTIAL IMPACT \\ ON THE SOUTH AFRICAN ECONOMY
}

\author{
RICHARD C. PORTER \\ Department of Economics \\ University of Michigan
}

The purpose of this paper is to clarify the theory of international economic sanctions and to provide estimates of the short-run economic impact on South Africa of externally imposed reductions of the imports and capital flows into that country. A macroeconomic picture of South Africa's "dependence" is drawn, and the economy's vulnerability in the short run is seen to be in its capacity to import, not in exports or capital flows. Trade and capital sanctions most clearly damage South Africa's growth potential; the short-run impact is harder to quantify. A static linear programming model of the South African economy is constructed in an attempt at this quantification. This model estimates that small sanctions would have small impact - i.e., if imports were reduced by less than onefourth, GDP would be cut by only about one half as large a percentage as imports. Larger import reductions cause greater damage. If imports were to be cut in half, not only would GDP be seriously reduced but massive unemployment and relocation of white labor would occur.

\section{INTRODUCTION}

For some time, and with increasing frequency, sanctions have been suggested as a means whereby the world community might force changes in South Africa's racial policies. But the resulting debate has been hampered by a lack of clarity about how sanctions are supposed to function and by a distinct shortage of refined empirical estimates of

AUTHOR'S NOTE: For their careful work on the data and the computer, I am indebted to A. Beyaert, K. Maskus, and J. Tempalski. For helpful comments on an earlier draft, I thank R. Barlow, T. Bell, E. Berg, W. Cotter, A. Deardorff, D. Myers, and M. Nziramasanga. I am also grateful to the Ford Foundation for its financial support. 
the potential impact of sanctions. The goal of this article is to alleviate those deficiencies.

The word "sanctions" covers a wide variety of international actions (see, e.g., Ferguson and Cotter, 1978). Here, we shall consider only one set of such actions, where South Africa's international trade of goods and factors of production is impeded by agreement among its trading partners. Thus, the initial impact of international sanctions-or boycott, or embargo, the words are here considered synonyms-is upon South Africa's exports, imports, and net inflow of foreign capital; the ultimate incidence is, as well, on the volume, structure, and growth of South Africa output, income, and employment.

The theory of how sanctions "work" is developed in Section II. Not surprisingly, the reviewed literature displays a variety of theories, not all equally plausible and not all consistent with each other. A broad picture of South African "dependence" is drawn in Section III, and a macroeconomic assessment made of what kinds of sanctions do and do not have a potential to damage South African welfare. The source of the potential damage is seen to be the deprivation of imports, and the impact on growth is seen to be much more certain than the short-run effect. A sectoral model is then constructed and exercised in Sections IV and V in order to generate quantitative estimates of the potential short-run impact of import reductions. The conclusions of the simulations, stated more fully in section VI, are essentially that small import reductions would have small impact but that significant import reductions would cause nearly proportionate reductions in South Africa's output plus extensive relocation and unemployment of white labor. ${ }^{1}$

\section{THE THEORY OF ECONOMIC SANCTIONS}

Although economists have written extensively about universal economic sanctions, the precise mechanism whereby sanctions are supposed to prove effective is not always clear, and several quite different

1. There are also four appendices which are too long to be included here. They are available from the Center for Research on Economic Development, Old Architecture Building, University of Michigan, Ann Arbor, MI. 48109, contained in Discussion Paper No. 77. In Appendix A, the model of Sections IV and V is fully displayed. In Appendix B, the derivation of the data and of the parameters of the model is described. In Appendix C, the sectoral production functions of the model are developed in detail. And in Appendix $D$, previous studies of sanctions that use input-output models are examined critically. 
mechanisms can be discerned in the reviewed literature. The goal of sanctions is clear and simple: to impose a reduction in economic welfare on the target country and thereby reduce its willingness to persist in antagonizing the world community. But even for this simple statement, two complexities should be noted. First, the "thereby" is critical, although there is neither logical reason nor historical evidence that political or psychological collapse inevitably follows economic hardship, no matter how great the hardship. ${ }^{2}$ Nonetheless, I intend to ignore this essentially noneconomic issue and focus on the link between the international imposition of economic sanctions and the ensuing loss of economic welfare. The second problem lies in the words, "target country." This simple concept is adequate only if we deal with a homogenous population, with each member identically affected by sanctions, which reaches policy decisions by consensus. In any application of sanctions to South Africa, it must be remembered that the target is white South Africans' welfare; indeed, the true objective presumably would be to reduce the sum of all white South Africans' welfares, individually weighted by their importance in the political process.

I begin with a "basic theory" of sanctions. For ease of exposition, this theory is aggregative, static, and neo-classical. ${ }^{3}$ After this "basic theory" is developed, five alternative theories of how sanctions are supposed to work will be briefly examined. To understand the "basic theory," it is sufficient to consider a hypothetical target country that produces and

2. Powerful recent evidence comes from North Vietnam: "the argument that the bombing would affect the will of Hanoi's leadership is generally based on three suppositions. First, the bombing would so reduce North Vietnam's capability to successfully prosecute the war that Hanoi would either sue for peace or substantially reduce the level of warfare. Second, the leadership would decide that the level of destruction visited upon the North Vietnamese economy was greater than the gain from supporting the revolution in the South. Or third, that the morale of the North Vietnamese population would so deterioriate that the leadership would be forced to seek relief from the bombing through negotiations or reduced support for the forces in the South.

Examination of the results of the bombing indicates that none of these suppositions have been borne out in practice." (Biles, 1972: 15).

One seeks in vain for evidence from Rhodesia, where real GDP grew at nearly $7 \%$ per annum during 1965-1974. Only in an opportunity-cost sense could it be said that there was hardship. In any case, it was not sanctions that humbled the white government of Rhodesia (see Porter, 1978a).

3. However, the empirical work in Sections IV and V is based on a model that is disaggregated (i.e., the economy contains eight sectors), and fixed-coefficient (i.e., much of the substitutability of neo-classical functions will be discarded in order to make the empirical work feasible). The empirical work there continues to be static, which means that it will be concerned only with the short-run implications of sanctions. 
consumes two commodities and initially trades freely at exogenously determined prices. For analytical simplicity, the possibility that factors of production also move is ignored. But we must remember that, for South Africa, labor and capital movements have always been important. Figure 1 displays the standard trade model, with the (concave) production possibility curve, the (convex) community indifference curve, and the optimizing trade possibility line, tangent to both curves. For maximum welfare $\left(W_{0}\right)$, the country produces $x_{0}$ and $y_{0}$, exports good $x$ and imports good $y$, and consumes $x_{1}$ and $y_{1}$. In Figure 2, a dashed community indifference curve $\left(W_{1}\right)$ is added which shows the highest welfare the country can attain if it is denied access to international trade; it produces and consumes $x_{2}$ and $y_{2}$; its welfare, $W_{1}$ instead of $W_{0}$, is clearly reduced.

Examination of Figure 2 indicates that the magnitude of this relative loss of real income will be greater (1) the less flat (i.e., more concave) is the production possibility curve, (2) the less flat (i.e., more convex) the community indifference curve, or (3) the greater the initial trade. In other words, sanctions which preclude trade will be more effective (1) the more inflexible the target country's production structure, (2) the more inflexible its consumption preferences, or (3) the greater its initial dependence on imports and exports. This last condition is the only one that is usually explicitly mentioned in the sanctions literature (see, for example, Maizels, 1964: 120-121). In light of these three conditions, it is easy to see why great things might be expected by the world community of sanctions against South Africa. Imports equal roughly one-fourth of South Africa's Gross Domestic Product (GDP); its exports are heavily dependent on a few minerals; and it might still be viewed as lacking the economic maturity that lends flexibility to a productive structure.

So far this basic theory has treated the degree of flexibility and dependence of the target country as essentially exogenous data. For the sanctioning countries, of course, this is correct; but an expectant target country can do much to increase its flexibility and reduce its dependence on imports (Arad and Hillman, 1978). One can readily envisage incorporation of duopoly-like threats and reactions into the model, but no formal extension is necessary to see its principal lesson: that the longer the world debates the imposition of sanctions, the smaller may be their effect when finally imposed. In South Africa's case, preparation for sanctions has meant not so much a reduction in dependence or an increase in flexibility as a build-up of stockpiles of critical imports, 


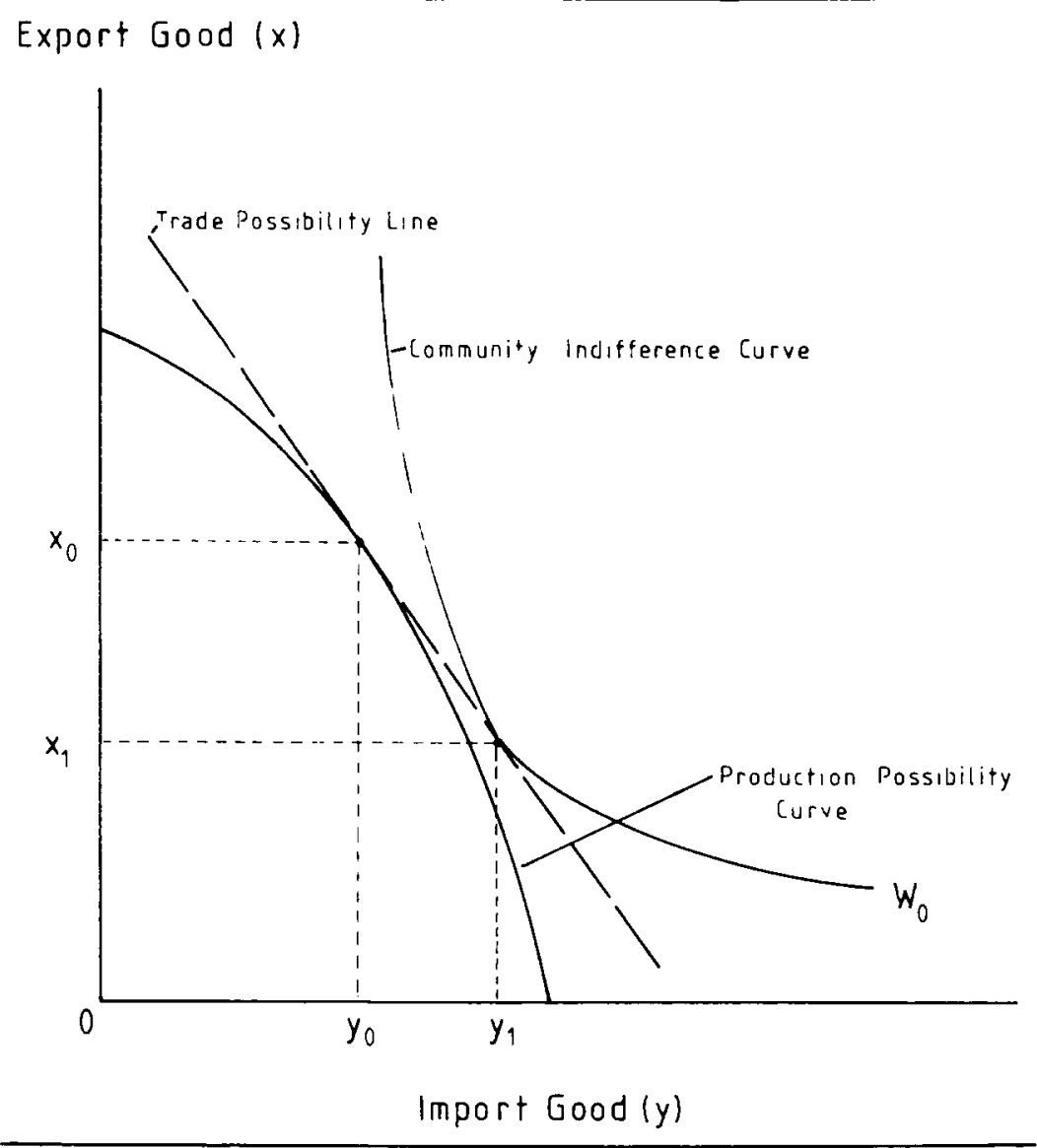

Figure 1

particularly oil. Recent estimates of the size of South Africa's oil inventory suggest one and a half to two years (Raiford, 1978: 57; Bailey and Rivers, 1978; 58).

The basic theory above is also developed on the assumption that sanctions are universal-that is, they completely prevent all imports into the country. If only some countries impose sanctions, the impact depends critically on the extent to which the target country can acquire the same imports from other sources. (The potential for sanctions imposed by all countries but only on certain kinds of imports is dis- 


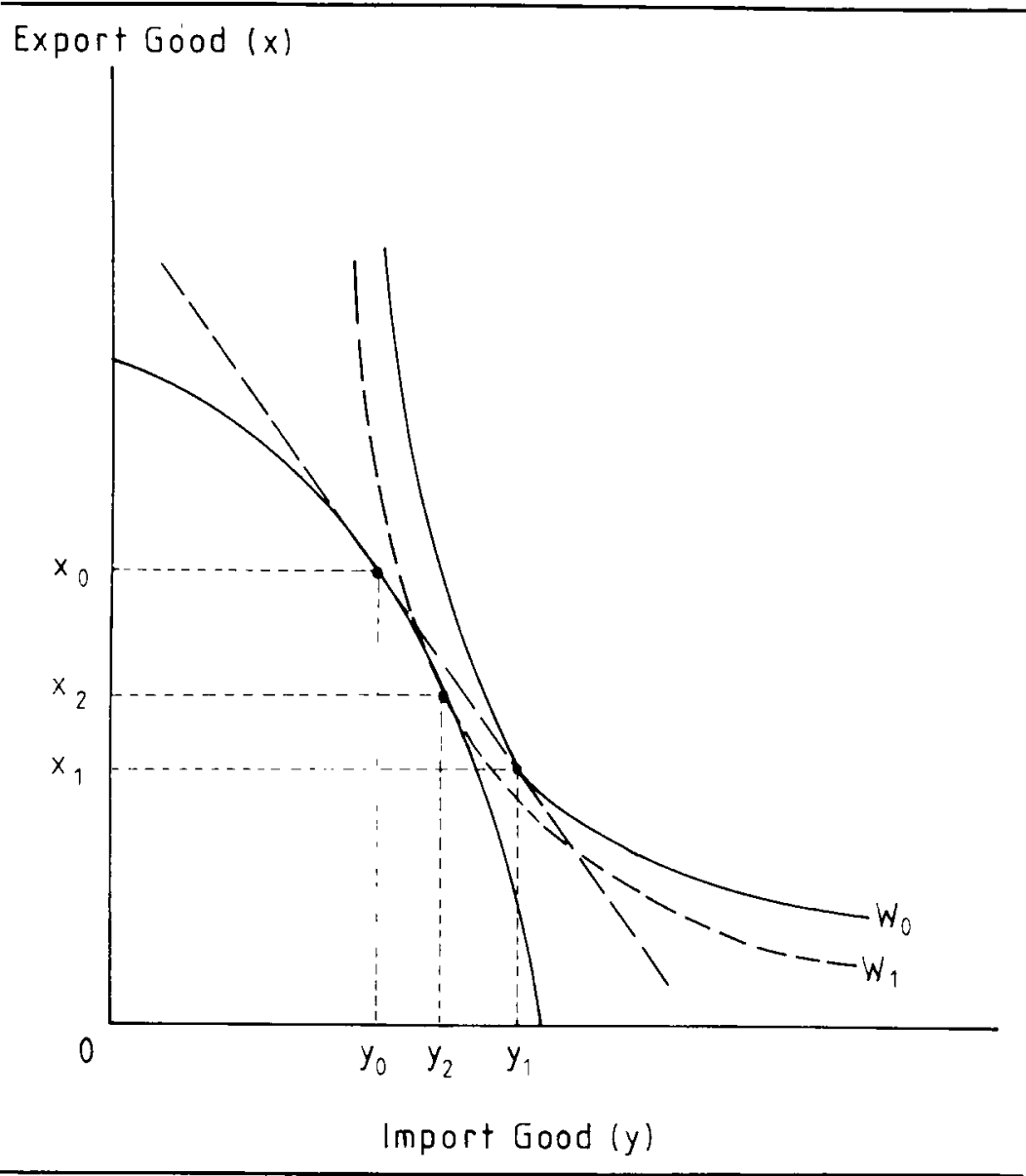

Figure 2

cussed later.) Again, a formal model-incorporating limits to the target country's exports and imports-is not needed to see the principal qualitative result: partial sanctions achieve partial results.

While the foregoing analysis and conclusions seem straightforward, there are alternative theories about the connection between sanctions and welfare:

(1) Sanctions which apply only to certain exports and/or imports may be effective if there are inflexibilities in particular areas of consumption or (more plausibly) production in the target economy. In the 
South African context, partial sanctions might be effective if they can (a) somehow "clog" fiscally the South African economy with inexportable minerals or (b) damage South African production through the scarcity of critical raw materials (particularly petroleum). The clogging possibility can be seen in Figure 2; if the policy-makers of the target country cannot (or dare not) force a reduction in export-good production (from $\mathrm{x}_{0}$ to $\mathrm{x}_{2}$ ), the final welfare position is reduced even below $\mathrm{W}_{1}$ (as production and consumption of the import good is reduced below $y_{2}$ to $y_{0}$ ). Although this happened to some extent in Rhodesia (with tobacco), it seems less likely to arise in South Africa (with gold and diamonds) and will be ignored hereafter. The possibility of bottlenecks due to scarcity of particular imports is more relevant and could be examined through a sufficiently disaggregated model. Unfortunately, our later simulations deal with eight sectors, which is hardly disaggregated enough.

(2) Sanctions may cause a reduced growth rate. Even if the static real income losses are not large, they represent losses at the critical margin and increasingly will show up as inefficiency in the use of labor and capital, reduced saving (and investment) rates, and hence a lower rate of growth of output. By focusing on growth, and hence the long run, this alternative suggests the need for patience and persistence in the use of sanctions. It also assumes that foregone growth, even without an actual decline in living standards, will weaken the target country's resolve. This theory conflicts with the basic theory more directly than it at first seems. Static analysis assumes that the elasticity of substitution in both production and consumption increases, the longer the period considered. Thus, for the basic theory, sanctions must work quickly, for they are increasingly averted by long-run adjustment. The empirical work in Sections IV and $V$ is based on a simple model that does not consider saving, capacity growth, or time, and therefore does not examine this alternative to the basic theory, but it is discussed in the next section.

(3) According to a more Keynesian view of sanctions, one should focus on the lost exports which represent a decline in aggregate demand and, after the operation of the multiplier, result in recession and unemployment (presumably of whites as well as blacks). This is a very different approach to sanctions. It is entirely demand-focused, whereas the basic theory is entirely supply-focused. Accordingly, the policy implications also differ. In neither view is it necesasry to impose sanctions on both sides of the export-import trade. In the basic theory, the critical sanctions are against imports-in terms of Figure 2, if the 
country continues to export but is unable to import, its consumption bundle will be somewhere within the production possibility curve, and its welfare level therefore even lower than $\mathrm{W}_{1}$-in the Keynesian model, the critical sanctions are against exports, although sanctions against imports will also have some effect to the extent that they lower the marginal propensity to import, and thus raise the multiplier. The difficulty with this Keynesian, aggregate-demand model is that it must be assumed that the target country is unable either to recognize the source of its reduced real income or to undertake the expansionary macroeconomic policies necessary to offset the losses in export demand. Both of these assumptions are dubious in general, and in the South African context especially unwarranted - the imposition of international economic sanctions will surely be accompanied by increasing internal and external pressures that will warrant increased defense expenditure. Any aggregate-demand impact of economic sanctions is hereafter ignored.

(4) According to a dualistic view of the South African economy, there is an "unlimited" supply of black labor available to the modern white-directed ind ustrial, mining, and agricultural sectors at a low, constant, and essentially irreducible wage. Under this assumption, little of the damage imposed by sanctions can be shifted to blacks; and hence even a quite small impact on aggregate variables may be critical to the wages, profits, employment, consumption, and welfare of the relatively small white ruling community (see Porter, 1978 for the South African case). In fact, however, black laborers employed in the cities of South Africa earn wages well above the rural standard of living. Their first and greater unemployment as a result of sanctions would mean that blacks as well as (or instead of) whites suffered from sanctions.

(5) Finally, there is a view of sanctions that sees their effects as perverse (from the position of the countries imposing the sanctions). This theory begins with the belief that economic development requires a poor country to free itself of dependence on the export of primary products; hence the appropriate development policies include government encouragement of agricultural self-sufficiency and increased protection of industrial production. Thus, economic sanctions may force the target country to adopt the very policies needed for its own development. Of course, for best results (from the target country's viewpoint) the sanctions must be partial, effective enough to induce industrialization but not so effective as to make it impossible. Very few writers take this extreme position on the working of economic sanctions (e.g., Hoogevelt and Child, 1973), and in any case the argument is much 
less appropriate for South Africa than it might have been for Rhodesia since the South African economy has already undergone such extensive industrialization and import substitution. This view is ignored in the empirical effort of Sections IV and V.

\section{THE DEPENDENCE OF SOUTH AFRICA}

"Dependence" has been variously defined and much debated in the literature on economic development. Here, I want to use the word in the sense suggested by the preceding theoretical discussion, namely, the extent to which South Africa is vulnerable as a target for international economic sanctions.

This vulnerability is usually thought to be primarily in the target country's exports, partly because the very word "boycott" has come to mean a concerted refusal to buy rather than to sell, and partly because whatever success was achieved by the sanctions applied against Rhodesia ${ }^{4}$ occurred largely through the refusal of the world markets to accept Rhodesian tobacco. The impact of such a reduction in exports follows from the concurrent loss of earnings of foreign exchange and hence the ability to purchase essential or highly desired imported goods.

In South Africa's case, it may be difficult to muster a sufficient world consensus in practice against the purchase of exports as a means of denying South Africa foreign exchange. First of all, nearly half of South Africa's exports are the most eminently acceptable commodity of all: gold. Gold exports were R 2,565.3 million in 1974 out of an export total of $R$ 5,571.3 million (excluding re-exports). (The South African rand [R] was worth US $\$ 1.40$ before 1975 and US $\$ 1.15$ after.) And one half of the remaining exports are readily marketable mineral outputs, raw or slightly processed, which are sufficiently homogeneous to enter world markets with few distinguishable South African markings. ${ }^{5}$ It will not be easy for the world to reduce significantly South Africa's foreign exchange availability. An alternative would be world sanctions aimed

4. For a discussion and explanation of the notable lack of success of the Rhodesian sanctions, during 1965-1975, see Porter, 1978a. But Rhodesian exports were reduced, in 1968 , to an annual rate $39 \%$ below their 1965 annual rate. (They rose again thereafter.)

5. These are (in 1974): crude materials excluding fuels (SITC 2), R 594.2 million; nonmetallic mineral manufactures (SITC 66), R 374.3 million; iron and steel (SITC 67), R 217.2 million; and nonferrous metals (SITC 68), R 290.9 million. The total is $R$ 1,476.6 million, $49 \%$ of total nongold exports. 
directly at restricting South African imports. But this also may be difficult to achieve in practice as long as South Africa has the foreign exchange to pay for imports.

Whether imports are cut off directly or indirectly (through a reduction in South Africa's ability to export and hence its ability to pay for imports), the critical question remains: what damage would the resulting import reductions impose on the South African economy? If one measures dependence on imports as the ratio of imports to output (GDP), South Africa is an average country in this respect, with imports amounting to about one-fifth of GDP. ${ }^{6}$ Of course, that fraction by itself divulges little because it says nothing of how easily South Africa can dispense with (previously) imported goods entirely or can introduce their production domestically. For this, one must turn to the composition of imports. South African trade data are elaborately reported by both SITC and ISIC (i.e., by source sector), but they are most interestingly viewed by use, as in Table 1 .

The industrialization of South Africa over the last half century has not been atypical. As white incomes rose, consumer goods became manufactured domestically, and the intermediate inputs needed also became increasingly produced domestically. Accordingly, the importance of consumer goods and intermediate inputs declined in total imports. Simultaneously, low tariffs on capital equipment, maintained to encourage investment and reduce manufacturing costs, insured that domestic capital goods production lagged, and capital equipment became an ever larger portion of total imports (Zarenda, 1977). Indeed, as import-substitution industrialization proceeded into its later, more technologically advanced and capital-intensive stages, not only did the dependence on imports of capital equipment intensify, but the ability to produce intermediate inputs domestically failed to keep up. Thus, the decline of intermediate inputs in total imports decelerated.

Though brief and oversimplified (see Houghton, 1976: Chs. 6 and 8 for more details), this account of South African industrialization indicates its point of vulnerability to sanctions. Reduced capacity to import would not have much direct impact on consumer welfare. Less than $10 \%$ of total consumption is imported, and much of this is "luxury" consumption, easily expendable in a time of crisis. The brunt of sanc-

6. The countries reported in Kindleberger and Herrick, 1977:284, range from nearly zero to $76 \%$, with 33 below South Africa and 39 above. The median there of imports/GDP is $21 \%$. It should be noted that the Rhodesian ratio was over $30 \%$ in 1965 . 
TABLE 1

South African Imports, by Use, $1974^{\mathrm{a}}$

\begin{tabular}{lccc}
\hline & & \multicolumn{3}{c}{ (R millions) } \\
\cline { 2 - 4 } Category of Import & 1957 & 1964 & 1974 \\
\hline Intermediate inputs $^{\mathrm{b}}$ & $560.2(51.0 \%)^{\mathrm{e}}$ & $645.5(42.2 \%)^{\mathrm{e}}$ & $2,045.9(41.7 \%)^{\mathrm{e}}$ \\
Consumer goods $^{\mathrm{c}}$ & $231.4(21.1 \%)$ & $322.7(21.1 \%)$ & $775.5(15.8 \%)$ \\
Capital goods $^{\mathrm{d}}$ & $306.4(27.9 \%)$ & $556.2(36.4 \%)$ & $2,047.4(41.7 \%)$ \\
Total $^{\mathrm{f}}$ & $1,098.3$ & $1,529.9$ & $4,905.1$ \\
\hline
\end{tabular}

a. Source: Dept. of Statistics, South African Statistics, various years, table entitled "Imports by Use and Stage of Processing."

b. Includes "raw (or crude) materials" and "processed or manufactured materials" other than "capital equipment."

c. I.e., "articles ready for retail sale or consumers' use."

d. I.e., "capital equipment."

e. Figures in parentheses are percentages of totals.

f. Columns do not sum to total because two minor hard-to-classify categories are omitted.

tions would be felt in the other two categories of imports, intermediate inputs and capital goods.

For intermediate inputs, analysis at the highly aggregate level at which this section deals yields no insight into the potential effect of sanctions. For that, one must examine the composition of these inputs and estimate the extent to which they can be replaced by domestic production and at what resource cost. A systematic effort to do this is the chief thrust of the next two sections.

For capital goods, analysis at the macrolevel yields a great deal of insight. Imports of capital equipment currently comprise more than one-third of total South African gross domestic fixed investment, ${ }^{7}$ and the South African construction sector provides $70 \%$ of the remainder. Although South Africa has for some time recognized (and worried about) its almost total dependence on capital goods imports, it is still accurate to say that South Africa imports almost all of its capital equipment - with domestic industry essentially providing only the plant in

7. In $1974,33.9 \%$ ( $R 2,047$ million of $R 6,026$ million). This percentage has remained quite stable over the past two decades: in 1964, 34.7\% ( $R 556$ million of $R 1,605$ million); and in 1957, 32.7\% (R 306 million of R 936 million). (Source for gross domestic fixed investment data: 1.M.F., May 1978.) Put differently, imported capital goods made up $79.0 \%$ of the total equipment content of fixed investment in 1974 ( $R$ 2,047 million out of $R$ 2,593 million; source of latter figure: South Africa Reserve Bank, March 1978, p. S-81); these figures may not be exactly comparable, but they are suggestive. 
which it is housed. Thus, if sanctions were to cut off South Africa from capital equipment, South Africa's growth should effectively cease. Indeed, as time went and depreciation became relevant, the output potential of South Africa would be reduced unless it could rapidly develop from a very undeveloped base its own capital goods industries. No elaborate model is needed to conclude that sanctions against South Africa could be effective in the sense that South Africa's growth as a modern, industrialized economy could be dramatically interrupted. All studies I have seen agree on this (see, e.g., Marvin, 1964: 240 and Spandau, 1978: 271). Because this conclusion is so obvious, the model developed and applied in the next two sections is only concerned with the short-run impact of sanctions.

Besides trade, there is a second way in which South Africa is dependent on the world economy: for its net inflow of factors of production. Consider, first, capital. South Africa was a net debtor in the world community in 1976, as Table 2 shows, to the tune of nearly fifteen billion rands, a figure that is roughly half its GDP. Needless to say, few discussions of sanctions against South Africa fail to consider the "disengagement" or "withdrawal" of foreign capital.

The process whereby sanctions on international investment damage the target economy is more subtle than the theory about trade sanctions, and misconceptions abound. To begin with, the very words "disengagement" and "withdrawal" invite misinterpretation. There is no possibility that South Africa would permit the actual physical withdrawal of the capital equipment which is the counterpart of the foreign net asset position in South Africa. Should foreigners attempt to unload the shares, loans, mortgages, etc. that represent claims on South African output, they would threaten disorder in the financial and foreign exchange markets of South Africa, but they would not reduce the economy's real capital stock one iota (Harvey, 1975). Of course, the financial disruption might make it difficult for South Africa to operate this capital at capacity (Myers et al., 1978). The most that "disengagement" can mean, therefore, is the cessation of new (and replacement) investment. It might also mean, in the case of multinational corporations, that the parent would withhold personnel, intermediate inputs, and technological information from its South African subsidiary. With respect to personnel, withdrawal would be marginal, as South Africans now provide almost all the manpower, even at the highest levels, in their industrial establishment. With respect to inputs, the workings of the 
TABLE 2

Foreign Assets and Liabilities of South Africa, $1976^{\mathrm{a}, \mathrm{b}}$

\begin{tabular}{lrcc}
\hline \hline Category & Assets & Liabilities & Net Liabilities \\
\hline $\begin{array}{l}\text { Private sector } \\
\quad \text { Short-term }\end{array}$ & 989 & & \\
$\quad$ Long-term & & 2,660 & 1,671 \\
$\quad$ Direct & 1,787 & 6,343 & 4,555 \\
$\quad$ Nondirect & 368 & 6,684 & 6,316 \\
Government $^{c}$ & & & \\
Short-term $^{\mathrm{d}}$ & 1,221 & 2,235 & 1,014 \\
$\quad$ Long-term & 645 & 2,008 & 1,363 \\
Total & 5,010 & 19,929 & 14,919 \\
\hline
\end{tabular}

a. At end of year.

b. Source: South African Reserve Bank, March 1978, pp. S-64 through S-67.

c. Banks are included under "government."

d. Short-term assets include "gold reserves" and "SDRs."

sanctions follow the path already discussed for imports in general; the amount of damage hinges on the difficulty in South Africa of replacing the foregone imports from other (domestic or foreign) sources, or of doing without.

In the end, therefore, withdrawal of international investment is basically a growth-related threat. Except as a form of import sanction, it cannot have much short-run impact. Through its investment and technological components, however, such disengagement has a large potential impact on South Africa's rate of growth.

A second misconception about investment sanctions stems from a fascination with the ratio in South Africa of foreign investment to total investment; for example, "during the years 1970 to 1977, average annual foreign capital inflows amounted to $\$ 580$ million or 9.4 percent of gross investments" (Spandau, 1978: 197). The implication is that a one dollar reduction in foreign investment will lead to a one dollar reduction in total investment (or perhaps even a multiplied reduction of US $\$ 10.64$ [equals $\$ 1 / .094$ ] in total investment). The implicit macromodel is both naive theoretically and refuted empirically. In 1977, for example, the net capital inflow into South Africa fell to minus $\mathrm{R} 1,096$ million from plus $R$ 1,110 million in 1976, a drop of $R$ 2,206 million. Gross domestic investment fell from $R$ 8,608 million to $R$ 8,303 million, only 3.5\% (South Africa Reserve Bank, March 1978: S-81). Even lagged relationships are 
unlikely. In the early 1960s, foreign capital flowed out of South Africa for seven years, and real GDP in South Africa continued to grow at 5-6\% per annum throughout the period (Harvey, 1975: 21).

The real impact of any reduction in foreign (net) investment in South Africa must derive, in the short run, from its impact on the balance of payments. Inflow of capital permits South Africa to import more, for given exports, and hence achieve a higher level of welfare (if the additional imports are consumer goods), output (if they are raw materials), or growth (if they are capital goods). A reduction in this capital inflow would force South Africa to reduce its imports - even without trade sanctions being imposed and as a result the economy would suffer the same kind of short-run economic damage as with direct import sanctions.

Capital sanctions would, of course, invite retaliation. South Africa probably would, as Rhodesia did, react to a ban on capital inflows by banning capital outflows and, more critically, the remission of interest, dividends, etc. on foreign assets in South Africa. It is instructive to examine the joint impact on South Africa's balance of payments of world investment sanctions and such a South African retaliation. In Table 3 the South African balance of payments for 1972-1977 is shown. In parentheses are shown what the figures would have been in each year if (1) world investment sanctions had cut off all long-term capital movements into and out of South Africa, (2) South Africa had prevented all investment income, nontrade-related service payments, and transfers from moving into or out of South Africa and (3) trade had (somehow) not been affected by either of these events. ${ }^{8}$ It can be seen in Table 3 that the net effect of these changes would have worsened South Africa's "basic balance" in only three of the last six years. Indeed, if South Africa had altered its imports each year so as to have maintained the same basic balance with investment sanctions as it would have had without, its total imports for the six-year period would not even have contracted.

In sum, investment sanctions show much less potential than trade sanctions for causing a reduction in South African imports. In the model of the next two sections, we will make different assumptions about what happens to South African foreign capital flows (i.e., to the balance of trade) under sanctions; as might be anticipated from the

8. Travel is also assumed unaffected. The reason for excluding trade effects is not (obviously) to write a realistic scenario but rather to isolate the potential balance-ofpayments impact of investment sanctions alone. In reality, of course, many of the capital flows are simply the financial counterparts of trade flows. 


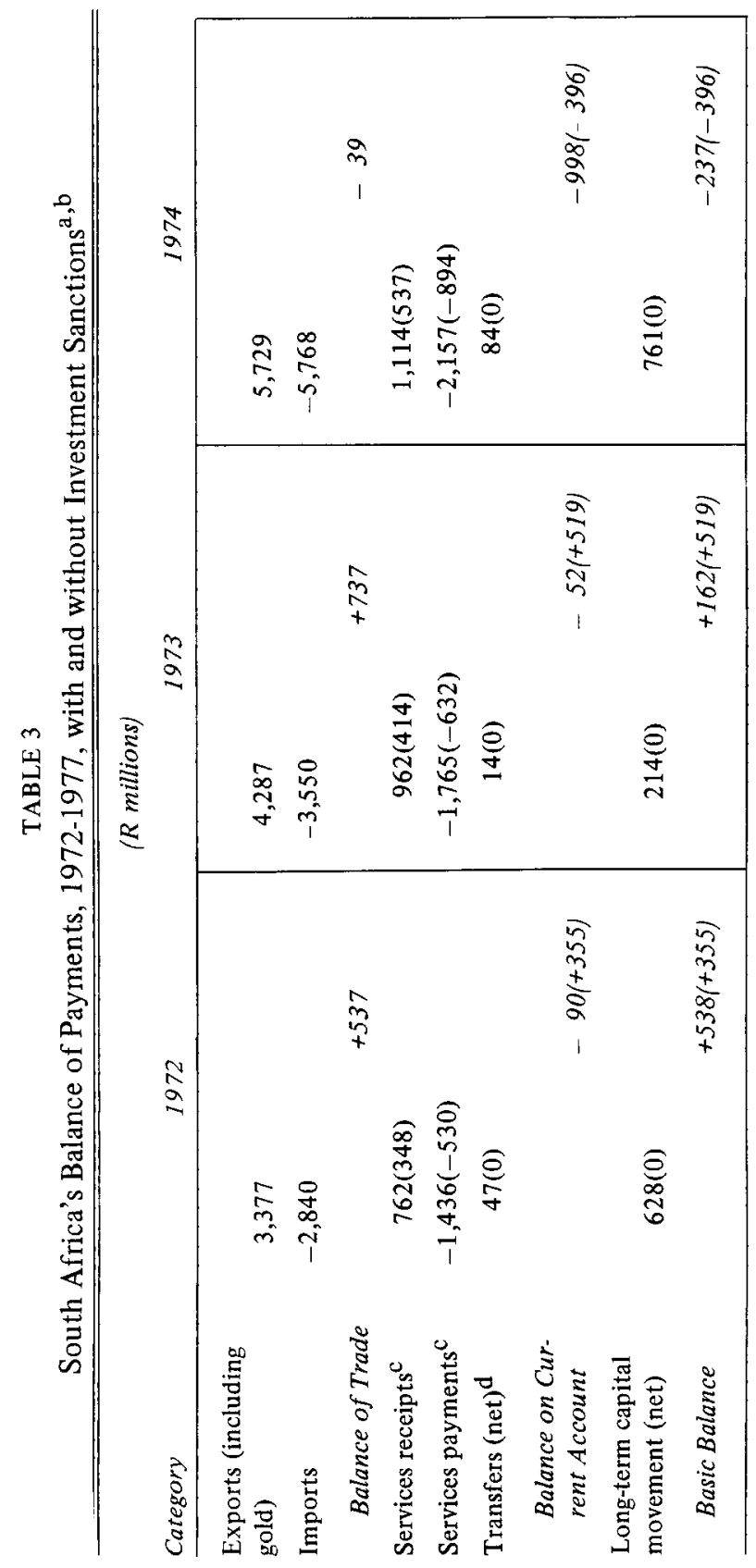




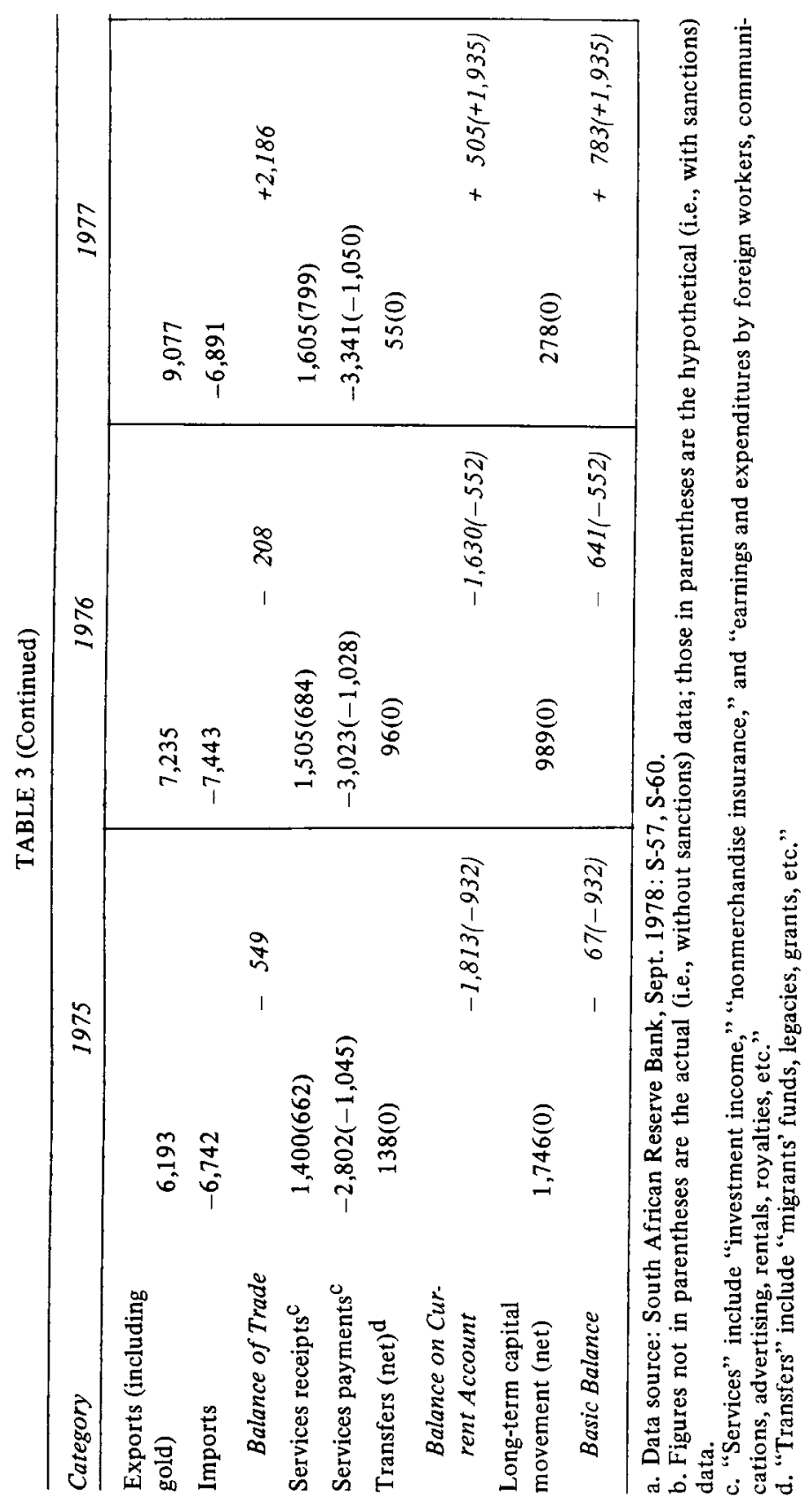


above discussion, the results in the short run, which is all the model will consider, are not very sensitive to this choice of assumption.

A second factor of production also migrates, in a net sense, into South Africa: labor. The "modern" part of the South African economy receives (net) both white and black labor through migration. International sanctions could attempt to reduce either or both of these flows. The magnitudes are not trivial. South Africa's white population currently has a natural rate of increase (i.e., birth rate minus death rate) of $1.2 \%$. Net immigration of whites has, over the past decade, been around 30,000 per annum, which has raised the growth rate of the white population by about one percentage point. White immigration supports the white polity and economy in a number of well-known ways. The availability of black labor from neighboring countries helps to ensure an unlimited supply of low-opportunity-cost labor (see Porter, 1978; this flow has recently been much reduced, supposedly for political reasons). However, since sanctions along these lines are rarely discussed, I shall ignore them in the work of the next two sections.

In summary, there are two basic kinds of sanctions, trade sanctions and capital sanctions, and two general kinds of impact, in the short run and on growth. South Africa's extreme dependence on imported capital goods makes it very probable that its growth would be critically affected by a reduction in its ability to import. And investment sanctions which reduced its access to new technology would also hurt its growth potential. The impact of sanctions in the short run, however, is much less clear. Sanctions which cut off capital inflows into South Africa would almost surely be met by retaliatory bans on outflows, and the overall short-run effect on imports and output would probably be small. Sanctions which directly reduced imports would certainly directly affect South Africa's output, but by how much is an empirical issue which hinges essentially on the flexibility and adaptability of the South African industrial structure. The model developed and exercised in the next two sections is intended to provide some insight into this flexibility, and hence some idea about how much South African output would be reduced by an externally imposed reduction in its imports.

\section{A MODEL TO ESTIMATE THE IMPACT OF SANCTIONS}

In this section, a model is developed to estimate the short-run effects on the South African economy of various trade and investment sanc- 
tions that might be imposed. The model is static, in the sense that the initial capital stock is taken as given throughout, in total and by sector, so that the estimated effects of sanctions can be thought of as those occurring in the short run-a period long enough that initial stockpiles become irrelevant but short enough that compensatory growth and movements (and depreciation) of capital are not yet critical. The model is consistent in the sense that the total supplies from all sources of each output and input must be adequate to provide the total demands for all uses. And the model relies on input-output relationships-for the output of each of the eight sectors considered, there are needs for inputs of seven kinds of labor, intermediate-good imports, intermediate goods from each of the eight domestic sectors, and plant capacity.

Two ingredients of the model which critically underlie the estimates of the impact of sanctions (calculated in the next section) require discussion before turning to the details of the model. First, it is assumed that the South Africans react optimally to sanctions; that is, they maximize a social objective function, subject to the constraints imposed upon them by sanctions. This means that the model specifically ignores those theories of sanctions that work through reduced aggregate demand or target-country policy failure or inertia. In this sense, therefore, the resulting estimates are of the minimum impact of sanctions. South African policy ineptness, confusion, or inadequacy could immeasurably compound this impact.

And second, it is assumed that there is some substitutability in South African production functions. If there were none, then, except as unnecessary final-demand imports could be curtailed, any reduction in imports would mean reductions in intermediate-good imports; this, in turn, would cause a proportionate reduction in the output of the sector for which they were destined and unemployment of a proportionate amount of labor and capital there. Such an assumption would be extreme, as is shown by both South Africa's specific imports at the detailed microeconomic level and the evidence from Rhodesia for the late 1960s. ${ }^{9}$ But the other extreme, to assume that South African labor and capital could readily provide a replacement for any import, is equally untenable. We shall assume that, even in the short run before new capital can be installed, South African factors can replace imports to some

9. Rhodesia's real GDP fell only in 1966 , by $4.4 \%$, while its imports fell by $29.4 \%$. Real GDP began to rise again in 1967, even though imports did not regain their 1965 level until 1971 (Porter, 1978a). 
extent but at high cost. That is a broad outline of the ingredients of the model. The rest of this section explains the model in greater detail, but still entirely in words. ${ }^{10}$

The discussion below is first of the constraints on South Africa's economic activity, and then of the objective function of South African policy-makers. There are three kinds of constraints: (1) technological constraints, (2) external constraints imposed through international sanctions on imports into South Africa, and (3) constraints which South Africans choose to impose upon themselves. This third group of constraints perhaps needs a few words of general explanation, as it appears inconsistent to try to maximize an objective function and simultaneously to restrict one's actions in that effort. Some of these constraints are historically, culturally, or behaviorally sufficiently entrenched as to be either unrecognizable to South African policy-makers as potential policy tools or not susceptible to change even under conditions of crisis. Others of these constraints are really part of the objective function, but the extremely nonlinear way in which they enter makes it more convenient to consider them as policy constraints.

The technological constraints involve the relationship between the various inputs and each sector's output. For the most part, it is assumed that there is no substitutability between inputs, hence that there is a certain amount of each input required per unit of each sector's output. Thus, for each of the seven occupations and eight sectors, there are labor-output coefficients (56); there are also interindustry intermediategood input-output coefficients $(64$, though many are zero); there are intermediate-good import-output coefficients (8); and there are capitaloutput coefficients (since capital is unchanging and sector-specific in the short run, these coefficients enter simply through a maximum output level for each sector). Introducing substitutability - with less than an infinite elasticity of substitution-is difficult in a linear programming model, but it is essential for realism that there be some. Thus, one kind of substitution between inputs is permitted in the model, that labor can partially replace intermediate-good imports. In terms of Figure 3, if output under sanctions were to require labor and imports in the same ratios as before sanctions, the unit-output isoquant would be the solid right-angled line, $a \beta \gamma$. In the model we shall assume instead that such imports can be economized if sufficient new labor is employed; hence a

10. The equations of the full model are described in Appendix A; the data base and the parameter estimates are shown in Appendix B; and the precise nature of the substitutability between labor and imports is developed in Appendix C. (See footnote 1.) 


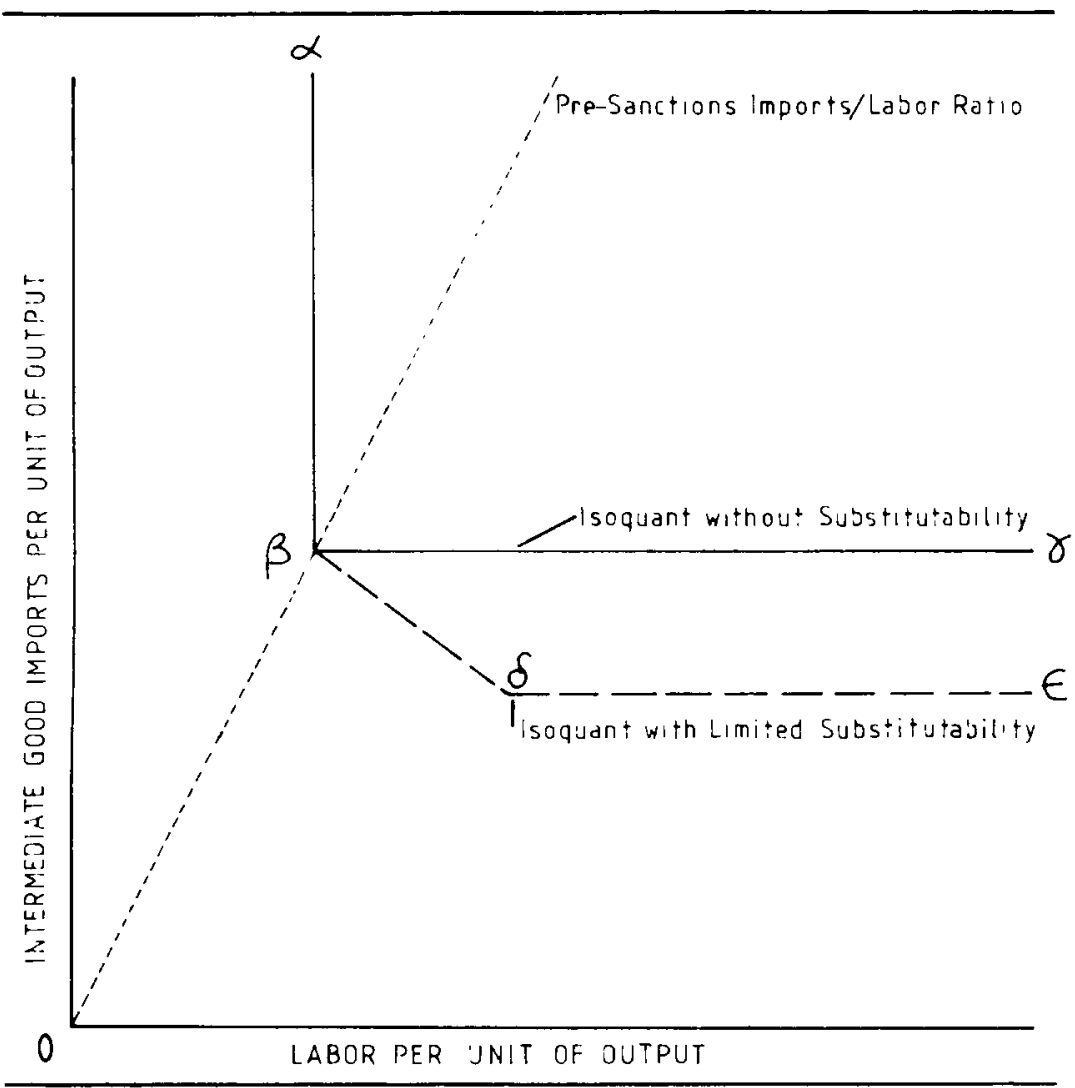

Figure 3

range, $\beta \delta$, in which substitution can occur. The unit isoquant employed in the model is therefore the partly solid and partly dashed line, $a \beta \delta \epsilon$.

Labor in the model is disaggregated into occupations (seven) and races (two) as well as sectors (eight). It would be clearly unrealistic to assume that, even in the short run, there is a fixed labor-output coefficient for each kind of labor and for each race. The very system of South African discrimination suggests the extent to which substitution is possible. Within any broad occupational category such as we are using -e.g., production or sales worker-blacks there will be trained to do only the lower-rung jobs and hence would be able to substitute for the better educated, better trained, higher-rung whites to only a limited 
extent, namely around the ladder rungs at which the races are divided. Thus, within any occupation, whites and nonwhites are assumed perfectly substitutable as long as the ratio between the two races remains within a certain percentage of the presanctions ratio; beyond that percentage no further substitution is possible. Because the occupational groups are so broad, it seems reasonable to assume that there is no substitutability in the short run between labor of different occupations. Finally, constraints were also included concerning the total number of workers in the more skilled occupations; this is intended to reflect the fact that, in the short run, the amount of labor upgrading and training that can be completed is quite limited.

The possible external constraints imposed on South Africa through international sanctions have been extensively discussed in the previous two sections. Here it need only be recalled that their common denominator-especially in the context of this model-is the withholding of crucial imports. The model treats this not as a direct curtailment of imports but rather as a reduction in exports and/or foreign capital flows, which in turn means a reduction in foreign exchange earnings by South Africa and in its ability to purchase imports. In the next section, the extent to which exports and the balance of trade are affected by sanctions will be varied among simulations, but the effect is always to reduce imports, and thus the ability of the South African economy to produce output. The sanctions this model considers are always reductions in imports, but South Africa is always left free to determine the composition of its limited imports. Direct restrictions on the composition of imports could hurt South African GDP beyond the estimates made here.

Although it is difficult to forecast how policy-makers will react to a crisis of a nature and extent not previously ouserved, there are clearly constraints on what South African policy can do. We assume relatively few constraints; if there are more, and they are binding, then the GDP estimates of this model are biased upward (that is, the harm done by sanctions would in fact be greater than here estimated). The policy constraints in the model are the following:

(1) The long run must not be sacrificed; thus, the total and sectoral composition of investment is to be maintained (if possible).

(2) The need for government activity is not reduced because of the crisis; thus, total government consumption is to be maintained (if possible) and its sectoral composition varied only within narrow limits. 
(3) The sectoral composition of private consumption can only be varied, in the short run, within narrow limits. (This means, of course, that the implicit community indifference curve of Figures $I$ and 2 is not a smoothly curved function.)

(4) Full employment of the white labor force is to be achieved (if possible).

(5) White laborers are not to be "uprooted" (if possible); thus, the total number of white workers in each occupation-and-sector is subject to change only within narrow limits.

The objective of South African policy-makers, once faced with sanctions, is assumed to be simply the maximization of total output, or GDP. Other objectives were considered-such as the maximization of total white (wage plus nonwage) income or consumption-but, given the model and its constraints, this seemingly important change did not much affect the results of the simulations.

\section{ESTIMATES OF THE IMPACT OF SANCTIONS}

This section, which estimates the impact of sanctions (according to the model described in the previous section), is divided into four parts. First, a baseline picture is established of a South African economy that is prepared for, but not yet actually subject to, sanctions. Second, the economy is simulated, through the model, as if it were subject to sanctions which reduced its exports and capital inflows by various across-the-board percentages. Third, the sensitivity of the results to changes in parameter values and assumptions is explored. And finally, a "greatest impact" of sanctions is estimated by moving simultaneously all parameter values and assumptions to their most damaging while still plausible extremes.

A baseline picture of the South African economy without sanctions must be drawn in order to estimate the impact of sanctions. Although the actual official South African statistics of some recent year would seem to provide an adequate base, there are two problems. First, the data needs of the model are sufficiently great that the year 1967 had to be chosen as the base. (Note that the real GDP rose by about one half between 1967 and 1977.) Moreover, since data from different official sources had to be molded into one internally consistent set, the base year "1967" that emerged is not exactly the same, in most of its statistical components, as any official South African "1967." 
The second difficulty with using actual data as a basis for comparison is that South Africa has never urgently anticipated the imposition of sanctions. Thus, the proper comparison, for estimates of the impact of sanctions, is between South Africa under sanctions and a South Africa prepared for, but not actually suffering from, sanctions. The very preparation process, which would presumably achieve a fuller utilization of existing supplies of capital and labor, might itself raise South Africa's GDP. Accordingly, the base year itself requires simulation. This picture of South Africa, before sanctions but prepared for sanctions, is created by running the optimizing model with exports and imports constrained to be no greater than their actual 1967 levels.

The "actual" data of 1967 , and the hypothetical model-generated 1967 data of a South Africa prepared for sanctions are compared in Table 4. "The model indicates that two notable changes occur in this process of becoming prepared. First, exports and imports are reduced about $6 \%$. This seems curious in that sanctions have not yet been imposed, but what it actually reflects is a large reduction in luxury consumption imports and a simultaneous reduction in the need to export to pay for them-and hence a release of export-labor for production in crucial domestic activities. And second, GDP is expanded by $3 \%$, chiefly by the use of more nonwhite labor. The figures in the "prepared" column of Table 4 are the base-year data to which all subsequent simulations are compared.

There is an infinite variety of trade sanctions that could be applied to South Africa--different combinations of sanctioning countries, different combinations of prohibited exports (to South Africa), and different degrees of success in applying those sanctions. The model is too aggregated (and too expensive) to explore this variety fully. Here, we will look primarily at across-the-board sanctions, meaning that the maximum value of each sector's exports and the net capital flow (i.e., the trade balance) is reduced, through sanctions, by some percentage. The simulations consider these cuts in $10 \%$ jumps, from $10 \%$ through $60 \%$. Such across-the-board, but less than $100 \%$, sanctions can be interpreted as a less than complete world involvement in the sanctions and/or a less

11. The fact that the two differ indicates either the extent to which the model is inaccurate or that the economic objectives of South Africa, when not sanctioned, involve other variables than GDP. I am assuming it is largely the latter. Indeed, the larger GDP with "preparedness" may well require policy actions that are dysfunctional for the economy under normal circumstances (a point suggested in correspondence by Desaix Myers). 
TABLE 4

The Actual and Prepared South African Economy, 1967

\begin{tabular}{|c|c|c|c|c|}
\hline \multirow[b]{2}{*}{ Statistic } & & \multicolumn{2}{|c|}{$\begin{array}{l}\quad(R \text { millions) } \\
\text { South A frican "Data," } 1967\end{array}$} & \multirow{2}{*}{$\begin{array}{l}\text { Percentage } \\
\text { Difference }\end{array}$} \\
\hline & & Actual & "Prepared" & \\
\hline \multicolumn{5}{|l|}{ Value added in } \\
\hline Agriculture & (1) & 941 & 1,009 & $+7.2 \%$ \\
\hline Mining & $(2)$ & 953 & 963 & +1.0 \\
\hline Manufacturing & (3) & 1,507 & 1,632 & +8.3 \\
\hline Construction & (4) & 413 & 414 & +0.2 \\
\hline Electricity & $(5)$ & 228 & 247 & +8.3 \\
\hline Trade & (6) & 632 & 653 & +3.3 \\
\hline Transport & (7) & 1,228 & 1,150 & -6.4 \\
\hline Services & (8) & 2,253 & 2,332 & +3.5 \\
\hline Total (GDP) & & 8,156 & 8,400 & +3.0 \\
\hline Exports & (E) & 2,547 & 2,396 & -5.9 \\
\hline Imports & (M) & 2,440 & 2,289 & -6.2 \\
\hline Deficit & (D) & -107 & -107 & $-\mathrm{c}$ \\
\hline \multicolumn{5}{|l|}{ Wage income } \\
\hline of whites & & 2,740 & 2,747 & +0.3 \\
\hline of nonwhites & & 1,193 & 1,272 & +6.6 \\
\hline Nonwage income & & 4,223 & 4,382 & +3.8 \\
\hline \multicolumn{5}{|l|}{ Employment ${ }^{\mathrm{d}}$} \\
\hline White & & 1,190 & 1,190 & $-c$ \\
\hline Nonwhite & & 5,179 & 5,510 & +6.4 \\
\hline
\end{tabular}

a. See text for description of this term.

b. Prepared minus actual, divided by actual.

c. Const rained to zero.

d. Thousands of workers.

than complete success at implementing universal sanctions. The simulations cease at $60 \%$ across-the-board reductions simply because I felt that by then, the basic structure of the South African economy would surely have become so changed that the model could no longer adequately describe it.

The simulated results of these across-the-board percentage cuts are shown in Figure 4. The data for the zero "cut" represent the prepared but not yet sanctioned economy described earlier. $10 \%$ and $20 \%$ reductions have relatively small impacts on GDP and its components. GDP de- 


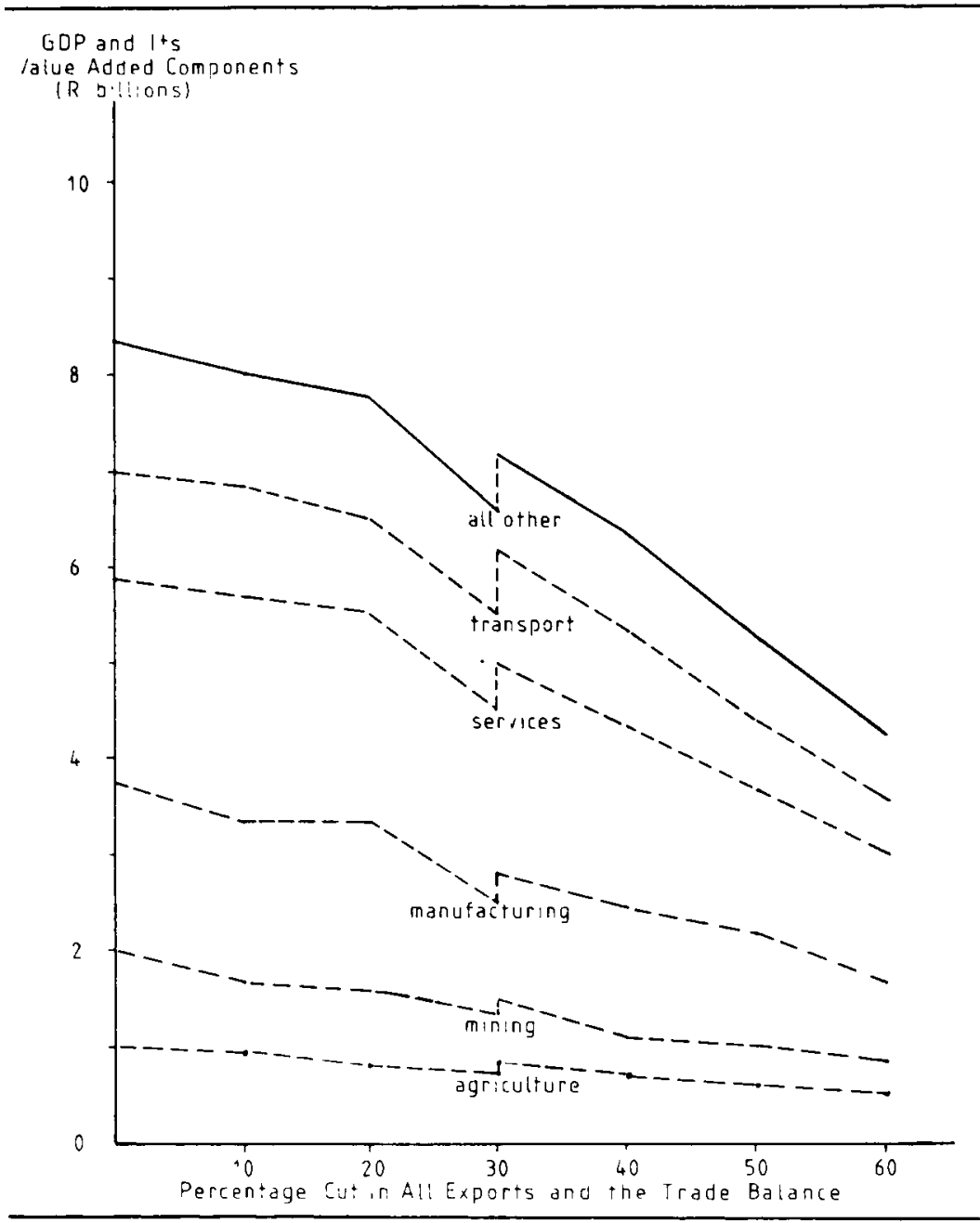

Figure 4

clines from $\mathrm{R} 8,400$ million to $\mathrm{R} 8,036$ million and $\mathrm{R} 7,811$ million, respectively. The implied elasticity of GDP with respect to sanctions is less than one-half - that is, for small reductions, an $x \%$ across-the-board cut in exports and imports causes a less than $1 / 2 \times \%$ cut in GDP.

The impact increases noticeably once $30 \%$ cuts are considered. GDP drops to $\mathrm{R} 6,575$ million, $21.7 \%$ below the prepared but not yet sanc- 
tioned level of $\mathrm{R} 8,400$ million. The cause of this increased impact is not hard to find. Initially, imports of finished consumption goods comprise $17.8 \%$ of total imports. When sanctions are applied, luxury consumption imports are foregone (by South Africa) first. These provide a cushion of expendable imports that prevent "light" sanctions from having much impact on real output. But, by the time $30 \%$ cuts are reached, consumption-good imports have fallen to only $8.5 \%$ of total imports, and the remaining consumption goods are not so readily surrendered. At somewhere between $20 \%$ and $30 \%$ effectiveness, sanctions begin to "bite."

At $40 \%$ across-the-board sanctions, there is no feasible solution to the model. By then, sanctions have become sufficiently constricting to the South African economy that all the technological, behavioral and policy constraints of the model cannot be simultaneously satisfied. The South African reaction must be to relax some of the policy constraints. Specifically, I assume that in this circumstance: (1) investment can no longer be held at its presanctions level but is only required to be at its presanctions ratio to consumption; (2) ditto for government expenditures; and (3) the "uprooting" of white laborers (i.e., their transfer to other occupations and/or sectors) will be permitted to whatever extent necessary. ${ }^{12}$ This less exacting set of policy constraints permits the South Africans to find a feasible solution under sanctions-imposed export cuts of $40 \%$ or more.

With the less exacting set of policy constraints, a 30\% across-theboard cut in all exports and the trade balance reduces GDP to R 7,002 million. (This is shown, in Figure 4, as the higher of the set of points above $30 \%$.) The implied elasticity of GDP with respect to sanctions remains less than one-half. But the achievement of this feasible solution is not without cost. Investment drops to $\mathrm{R} 2,082$ million, only $86 \%$ of its presanctions level. Similarly, government expenditures are reduced to R 820 million, also (perforce) $86 \%$ of their presanctions level. There is, moreover, some "uprooting" of white labor, particularly in two sectors (and in one of which, mining, white labor has historically proven the most troublesome in South Africa). In the process of achieving the feasible solution at $30 \%$ export cuts, there are 18 thousand white workers laid off in mining, a reduction of $31.0 \%$, and 19 thousand white workers withdrawn from the trade sector, a reduction of $15.8 \%$. Partic-

12. Subject still, of course, to a technological constraint on the rate at which new labor can be trained in the skilled occupations. The white full employment constraint is also relaxed, but white employment is then included in the objective function. 
ularly in mining, this may represent a politically intolerable shift in the structure of white employment.

Once the adjustment is made to the less exacting set of policy constraints, further across-the-board reductions in exports and the trade balance as a result of sanctions cause quantitatively ever more severe, but qualitatively similar, output reductions. As $40 \%, 50 \%$, and $60 \%$ sanctions are simulated, South Africa's GDP drops to $74.5 \%, 62.3 \%$ and $50.3 \%$, respectively, of its presanctions (but prepared) level. Clearly, sanctions at these levels can cause significant damage to South African GDP. The damage is not only in the loss of output. With $60 \%$ sanctions, $10.3 \%$ of the white labor force becomes unemployed (and nonwhite employment has fallen from 5,510 thousand in the presanctions situation to 4,530 thousand, i.e., by $17.8 \%$ ). And the uprooting of whites in certain sectors has reached immense proportions; for example, $37.4 \%$ of the white construction workers and $30.6 \%$ of the white manufacturing workers must be laid off (or reallocated to other sectors).

Two other basic variations of sanctions were examined. First, we have so far estimated the impact of sanctions which had "across-theboard" effects on exports - that is, which reduced the exports of all sectors by the same percentage; but South Africa's mining sector exports appear much less vulnerable to sanctions than are its other exports. Let us consider the extreme case where sanctions are completely effective against the exports of all sectors other than mining but are completely ineffective against the exports of the mining sector. This means a $100 \%$ reduction in the nonmining $55 \%$ of South Africa's total exports, ${ }^{13}$ and the results of this simulation of unbalanced sanctions can be meaningfully compared to across-the-board sanctions which achieve $50 \%$ or $60 \%$ reductions in each sector's exports under the less exacting set of policy constraints. In fact, the aggregate statistics of the miningexports-only simulation compare quite closely to the $50 \%$ across-theboard sanctions, as Table 5 shows. GDP and consumption are only slightiy lower. And white full employment continues to be achieved in the mining-exports-only situation, as it had in the $50 \%$ but not in the $60 \%$ across-the-board case. The difference between the two lies, as one might guess, in the mining sector. In the mining-exports-only simulation, value added and employment in mining are $80.4 \%$ and $225.0 \%$ higher, respectively, than in the $50 \%$ across-the-board simulation. In the

13. It is also assumed in this run that trade is balanced, i.e., that sanctions effectively stop all capital flows that might permit trade imbalance. 
TABLE 5

Comparison of Across-the-Board and Mining-Exports-Only Sanctions

( $R$ millions and thousands of workers)

\begin{tabular}{|c|c|c|c|c|c|}
\hline \multirow[b]{2}{*}{ Statistic } & & \multirow{2}{*}{$\begin{array}{c}\text { Prepared } \\
\text { But Not Yet } \\
\text { Sanctioned }\end{array}$} & \multicolumn{2}{|c|}{$\begin{array}{c}\text { Across-the-Board } \\
\text { Cuts of }\end{array}$} & \multirow{2}{*}{$\begin{array}{c}\text { Mining } \\
\text { Exports } \\
\text { Only }\end{array}$} \\
\hline & & & $50 \%$ & $60 \%$ & \\
\hline $\begin{array}{l}\text { Value Added in } \\
\text { Mining }\end{array}$ & (2) & 963 & 491 & 398 & 886 \\
\hline Total & (GDP) & 8,400 & 5,234 & 4,224 & 5,130 \\
\hline Consumption & (C) & 4,918 & 3,072 & 2,479 & 3,042 \\
\hline $\begin{array}{l}\text { Employment in } \\
\text { Mining } \\
\text { Total white } \\
\text { Total nonwhite }\end{array}$ & $(2)^{\mathrm{a}}$ & $\begin{array}{r}594 \\
1,190 \\
5,510\end{array}$ & $\begin{array}{r}336 \\
1,190 \\
5,461\end{array}$ & $\begin{array}{r}491 \\
1,068 \\
4,530\end{array}$ & $\begin{array}{l}1,092 \\
1,190 \\
5,388\end{array}$ \\
\hline
\end{tabular}

a. Production workers only.

$50 \%$ across-the-board case, nearly half the white (and nonwhite) mining workers must be laid off; while in the mining-exports-only case, the white (and nonwhite) mining work force must be almost doubled from its presanctions level.

The second variation examines the impact, ceteris paribus, of sanctions that affect the net capital flow differently from the trade flow. In the across-the-board simulations, each sector's exports and the balance of trade were all varied by the same percentage. Now, we consider a situation in which each sector's exports decline by some percentage but the balance of trade does not change. Since the balance of trade was positive in the base year, this is equivalent to assuming that net capital movements into South Africa were reduced by a larger percentage than were exports, thus that imports must also be reduced by a larger percentage. In the simulation actually undertaken, exports were reduced, across-the-board, by $30 \%$ and the balance of trade kept at its initial level. This meant that imports had to be reduced by (at least) $31.31 \%$. In order to see the difference between the effect of import cuts caused by trade sanctions and those caused by capital flow sanctions, we will compare these results with an across-the-board export and trade surplus reduction of exactly $31.31 \%$. Imports are reduced identically in the two cases, but the export total is reduced $30 \%$ in one case and $31.31 \%$ in the other 
with the same export sector composition. The difference, as one would hypothesize from the discussion in Section III, is slight; GDP differs by only $0.3 \%$ between the two cases.

Before conducting sensitivity tests, we should notice exactly where in the South African economy the critical pressure of sanctions is feltor more precisely, in the terms of the linear programming model and its optimization, which of the constraints are most binding (i.e., display the highest shadow prices) at the optimal solution. Rather than report on all the simulations, I will examine two in detail, the $30 \%$ and the $60 \%$ across-the-board export and trade balance reductions, both under the less exacting set of policy constraints.

At $30 \%$ sanctions, many of the foreign trade, import substitution and labor constraints are already seriously binding. If sanctions could be evaded to the extent that $R$ 1,000 of additional exports could be made, with $R \quad 1,000$ of additional imports being thereby acquired, the South Africans could raise their GDP by from $R 3,419$ to $R 3,987$, depending upon which sector did the exporting. If $R 1,000$ of additional capital inflow could be induced, South Africa could add R 3,135 to its GDP. Thus, on the margin (of $30 \%$ effective sanctions), each R 1,000 cut in South Africa's exports or capital inflow imposes a loss of output of R 3,000-4,000. Given the costliness of the export losses, the South African economy turns to intensive efforts at import substitution. But there are limits to this process in the short run, and these limits are reached in two sectors, manufacturing and electricity. Furthermore, the ability to reduce final goods imports, as a percentage of total deliveries, is exhausted for both private and public consumption. The limits of import substitution are not reached in the other sectors because of a scarcity of skilled white labor: an additional white laborer would permit sufficient new hiring of nonwhites, labor reallocation and extra import substitution to be worth R 1,549 in added GDP. ${ }^{14}$ Thus, at $30 \%$ effective sanctions, any sanctions-induced net white emigration would add further to the economic damage.

At $60 \%$ sanctions, several more constraints have become binding. A marginal gain of $R 1,000$ of exports would mean a GDP gain of from $R 4,871$ to $R 5,656$, depending on the sector from which the export is made; and a marginal $R 1,000$ of capital inflow would be worth $R 4,503$ in GDP. At $60 \%$ sanctions, the limits to import substitution have been reached in almost every sector except construction. Scarcity of white

14. While this figure seems low, compared to white wage rates, it must be remembered that this marginal white is employed in costly import substitution. 
labor no longer provides any constraint; to the contrary, white unemployment has become serious, alleviated only by downgrading whites to lower-rung jobs normally done by nonwhites.

Sensitivity tests were performed on the model by moving, individually and in combinations up and down by $40 \%$ of their basic values, many of the parameters of the model, especially those whose values were based more on intuition than evidence. In none of these tests was the solution value of GDP moved by as much as one percent, except when the parameters representing the maximum limits to import substitution by sector were altered. Let us look at the solution when these limits are all contracted by $40 \%$. With sanctions that effect across-theboard $40 \%$ cuts in exports and the trade balance and with the basic parameter values, South African GDP would be cut from $\mathrm{R} 8,400$ million (i.e., the presanctions but prepared level) to $\mathrm{R} 6,260$ millionthat is, by $25.5 \%$. If the simulation reducing the parameters limiting the scope for import substitution by $40 \%$, the GDP drops still further, to R 5,730 million, i.e., by another 6.3 percentage points.

In a way, the sensitivity tests tell us what we could well have guessed; namely, that one's estimate of the short-run impact of sanctions on South Africa depends importantly on the estimate of the limits to shortrun South African import substitution. But there is a more interesting interpretation of these results. The estimates of the impact of sanctions are not so sensitive as we might have expected to the estimates of the limits to import substitution. In each of the sectors, a careful, plausible guess was made as to these limits. Now these limits are arbitrarily cut by $40 \%$ of that guess. And the resulting estimates of the impact of $40 \%$ effective sanctions changed by only a few percentage points-i.e. from a $25.5 \%$ cut in GDP (from the presanctions, prepared level) to a $31.8 \%$ cut. ${ }^{15}$ In short, the sensitivity tests greatly raise my confidence that the estimates produced by the model are in the right "ball park" and are not highly sensitive to the largely intuited ingredients.

One final sensitivity test was performed, whereby all the arbitrary parameters were simultaneously moved to values $40 \%$ from their basic values in the direction which increased the damage to South African output resulting from sanctions. Specifically, this "greatest impact"

15. In other words, the estimates of impact moved by $25 \%$ ( 31.8 minus 25.5 , divided by 25.5 ) in response to a $40 \%$ change in the critical set of parameters. 
simulation with the less exacting set of policy constraints assumed the following:

(1) The South African objective function places heavy weight on white employment, to the point where R 2,000 of output (GDP) will be given up in order to employ one more white worker.

(2) Sanctions cut all exports and the trade balance to zero, except for mining exports, which continue undiminished. (Thus, maximum total exports are reduced by $54.8 \%$ and imports must be reduced by at least $52.8 \%$.)

(3) Import substitution is made still more costly, and its limit reduced by $40 \%$, in all sectors.

(4) The initial excess capacity in each sector is reduced by $40 \%$.

(5) The maximum number of new members that can be trained for the skilled occupations in the short run is lowered by $40 \%$.

(6) The extent to which blacks and whites are substitutable for each other, in any given occupation and sector, is narrowed by $40 \%$.

(7) The degree of flexibility in the sectoral composition of public and private consumption is reduced by $40 \%$.

This "greatest impact" simulation should be compared to the "mining exports only" simulation (see Table 5) since both incorporate the same export assumption. Worsening all the arbitrary parameters at once lowers the estimated GDP from R 5,130 million to R 4,591 million, an additional $6.4 \%$ (of the prepared but not yet sanctioned level of $R 8,400$ million). Thus, the output estimates are not too sensitive to this extensive parameter variation. ${ }^{16}$ Employment estimates, however, tell a different story. Whereas white full employment had been achieved in the mining-exports-only simulation, this greatest-impact simulation displays an $11.8 \%$ white unemployment rate (and a reduction also in nonwhite employment of $14.7 \%$ ). Thus, the employment estimates generated by the model, unlike the GDP estimates, are fairly sensitive to parameter variation.

\section{CONCLUSIONS AND CAVEATS}

Estimates of the impact of sanctions on South Africa depend critically on the kinds of sanctions one envisages, the extent to which

16. The reduction in the limits to import substitution alone reduced GDP by $6.3 \%$, so all the other changes make practically no difference. 
they are imposed and enforced, and whether one thinks of the short run or the long run.

Although the long-run analysis in this paper is brief, it seems clear that sanctions could seriously damage South Africa's growth rates. Cut off from access to new foreign technology and imported capital goods (not just the capital flow), South Africa could not continue to grow at anything like its historical rates of $5.5 \%$ over the past quarter century, $4 \%$ in the 1970 s (growth rates per annum of real GDP), and perhaps not at all.

The short-run impact of sanctions depends critically on the extent to which imports into South Africa are reduced. Capital, or investment, sanctions would probably not much affect such imports-especially after the expected South African retaliation cut off capital outflowand hence in themselves would not much affect South African production.

Direct restriction of South Africa's ability to import could have a serious impact, in the short as well as in the long run, on South Africa. How much impact would depend on the effectiveness of the embargo. If South Africa's imports were reduced by less than one-fourth, little economic damage would be inflicted - each one percentage point cut in imports would cause about a one half percentage point cut in GDP. Once imports were reduced by more than one-fourth, the damage would become more significant. The elasticity of GDP reductions with respect to import reductions rises to about one and one-fourth, as import reductions reach one-half. Should imports be cut by more than onehalf, massive unemployment and relocation of white labor (as well as of nonwhite labor) would have begun to occur.

There are four caveats to be noted before we conclude. First, models like the one developed and exercised here are inevitably stylized abstractions of the economy they try to represent. Anyone who has worked with sectoral optimization models (especially for LDCs) knows that they may occasionally - and not so occasionally as one would likegenerate nonsense, despite the fact that each ingredient seems a plausible if simplified representation of reality. The proper defense of the model developed here is hardly unbounded faith in complex mathematical modeling but rather a lack of confidence in the alternative, the hidden models that underlie gut reactions and broad judgments.

The second caveat follows the first. Even if the model is a sensible simplified replication of the South African economic structure, that structure might alter dramatically under the pressure of sanctions. The 
model, with its innately unchanging view of structure, might then forecast quite badly. While such structural change cannot be easily encompassed within a model, it must be remembered that it is also difficult to foresee without a model. This shortcoming is probably not too serious as long as our concern is with the short run. But conclusions about South African growth under sanctions require a strong implicit assumption about South Africa's ability to alter the structure of (i.e., create) its capital goods industries. To the extent that history provides evidence, it is that modern economies fare better than we might expect when struck by calamity (see, e.g., Hirshleifer, 1963). But this recent evidence includes no observations of economies so dualistic and so internally divided at the time of crisis as is South Africa today.

The third caveat, clear to the careful reader of Sections IV and V, is that the model does not remove our uncertainty about the impact of sanctions. Rather, it serves only to locate its source and circumscribe it. In the end, the estimates of the parameters of South Africa's potential for import replacement are largely guesses. The results are not terribly sensitive to variations in these guesses, but they nevertheless are dependent upon them.

Finally, one should recognize that the direction of error of the results is not clear. The model assumes that South Africa maximizes GDP under sanctions, and it would therefore appear that its actual GDP under sanctions would be surely lower than the model estimates. But the model specifies many structural rigidities-for example, in the composition of consumption and the mobility of white labor-that may in fact turn out to be quite flexible in a beleaguered South Africa. Accordingly, it is impossible to be sure whether the estimates (presented in Section V) are high or low.

\section{REFERENCES}

ARAD, R. W. and A. L. HILLMAN (1978) "Embargo threat, learning and departure from comparative advantage," mimeo.

BAILEY, M. and B. RIVERS (1978) Oil Sanctions Against South Africa. U.N. Centre Against Apartheid (June).

BILES, R. E. (1972) Bombing as a Policy Tool in Vietnam: Effectiveness. Staff Study No. 5, Committee on Foreign Relations, U.S. Senate (Oct. 12).

FERGUSON, C. and W. R. COTTER (1978) "South Africa: what is to be done." Foreign Affairs (Jan.). 
HARVEY, C. (1975) "Foreign investments in South Africa: the economics of withdrawal." Study Project Strategy Paper No. 15, in James.

HIRSHLEIFER, J. (1963) "Disaster and recovery: a historical survey." Rand Memorandum $\mathrm{RM}-3079-\mathrm{PR}$ (April).

HOOGVELT, A.M.M. and D. CHILD (1973) Rhodesia: Economic Blockade and Long Term Development Strategy. The Hague: Institute of Social Studies, Occasional Paper No. 25.

HOUGHTON, D. H. (1976) The South African Economy. New York: Oxford Univ. Press.

IBRD (1977) World Tables, 1976. Baltimore: Johns Hopkins Univ. Press.

IMF (1978) International Financial Statistics (May).

JAMES, R. R. [ed.] (1975) Foreign Investment in South Africa: The Policy Debate. Africa Publications Trust.

KINDLEBERGER, C. P. and B. HERRICK (1977) Economic Development. New York: McGraw-Hill.

MAIZELS, A. (1964) "Economic sanctions and South Africa's trade," in Segal.

MAR VIN, J. D. (1964) "Sanctions against South Africa: the impact and the aftermath," in Segal.

MYERS, D., R. HECHT, and D. LIFF (1978) U.S. Business and South Africa: The Withdrawal Issue. Investor Responsibility Research Center, Special Report 1977-D(April).

PORTER, R. C. (1978) "A model of the Southern Africa-type economy." Amer. Econ. Rev. (Dec.).

___ (1978a) "Economic sanctions: the theory and the evidence from Rhodesia." J. of Peace Sci. 3, 2 (Fall).

RAIFORD, W. N. (1978) "International credit and South Africa," in U.S. Corporate Interests in South Africa. Report to the Committee on Foreign Relations, U.S. Senate (Jan.).

SEGAL, R. [ed.] (1964) Sanctions Against South Africa. Harmondsworth: Penguin.

South Africa Reserve Bank, Quarterly Bulletin, various issues.

SPANDAU, A. (1978) Economic Boycott Against South Africa: Normative and Factual Issues. Labor Research Program, University of Witwatersrand, Report No. 17.

ZARENDA, H. (1977) The Policy of State Intervention in the Establishment and Development of Manufacturing Industry in South Africa. M.A. Thesis, University of Witwatersrand. 